\title{
Nöro-Yoğun Bakımda Beslenme ve Sağlıkta Yaşam Kalitesi
}

\section{Nutrition in Neurointensive Care and Health Related Quality of Life}

Osman Serhat Tokgöz ${ }^{1}$,

Şerefnur Öztürk²,

${ }^{1}$ Necmettin Erbakan Üniversitesi, Meram Tıp Fakültesi, Nöroloji Anabilim Dalı, Konya,

Türkiye

${ }^{2}$ Selçuk Üniversitesi, Tıp Fakültesi, Nöroloji

Anabilim Dalı, Konya, Türkiye

Geliş Tarihi/Received: 25 Şubat 2019

Kabul Tarihi/Accepted: 23 Temmuz 2019

Yazışma Adresi: Osman Serhat Tokgöz, Necmettin Erbakan Üniversitesi, Meram Tıp Fakültesi, Nöroloji Anabilim Dalı, Konya, Türkiye

e-posta: serhatnoroloji@yahoo.com.tr

ORCID

Osman Serhat Tokgöz

https://orcid.org/0000-0002-4919-0285

Şerefnur Öztürk

https://orcid.org/0000-0001-8986-155X

\begin{abstract}
Öz
Sağlıkta yaşam kalitesi günümüzde daha da artan bir önemle tıbbın tanı ve tedaviyi içeren bütün alanlarında tedavi ve izlemin ayrılmaz bir parçası olmuştur. Nöro-yoğun bakımda nörolojik açıdan en ağır, tanı ve tedavi süreci en yoğun hasta grubu izlenmektedir. Yoğun bakımda izlenmesi gereken nörolojik hastalıklar, kronik dönemde olduğu gibi akut ve şiddetli evrelerinde de yaşam kalitesini etkileyebilme potansiyeline sahip pek çok parametre içermektedir. Hastalıkların kendilerine ait yaşam kalitesi etkileri dışında, çok sayıda önemli parametre vardır. Bunları başlıca yoğun bakımda beslenme yetersizliği, ajitasyon, ağrı, cilt bütünlüğünün bozulması, kas iskelet sistemi etkilenmeleri, kardiyovasküler ve otonom etkilenmeler, ilaç yan etkileri ve çoklu ilaç etkileşimleri olarak sıralamak mümkündür. Bu derlemede nöro-yoğun bakımda beslenme ile sağlıkta yaşam kalitesi arasındaki ilişki gözden geçirilecektir.

Anahtar Kelimeler: Sağlıkta yaşam kalitesi, beslenme, nörolojik yoğun bakım

Abstract

Today health related quality of life with its ever increasing importance has become an inherent part of treatment and follow up in all departments of medicine including diagnosis and treatment. In neurointensive care unit, the severest patients with the most intensive diagnosis and treatment period are followed up. Neurologic disorders with neurointensive care requirement include so many parameters potentially affecting the quality of life in acute and severe stages besides in chronic term. Apart from the effects of these diseases on life quality, there are many other important parameters related to quality of life. It is possible to list chief parameters as malnutrition in intensive care unit, agitation, pain, disruption of skin integrity, musculoskeletal system involvement, cardiovascular and autonomous involvement, side effect of drugs and multidrug interactions. In this review, the relationship between nutrition and health related quality of life in neurointensive care unit will be reviewed.
\end{abstract}

Keywords: Health related quality of life, nutrition, neurointensive care

\section{Sağlıkta Yaşam Kalitesi ve Nörolojik Yoğun Bakım}

Sağlıkta yaşam kalitesi günümüzde daha da artan bir önemle tıbbın tanı ve tedaviyi içeren bütün alanlarında tedavi ve izlemin ayrılmaz bir parçası olmuştur. Genel olarak iyi olma hali olarak bilinen sağlıkta yaşam kalitesi (SYK) Dünya Sağlık Örgütü tarafından bireyin içinde yaşadığı kültürel değerler ve kendi beklentileri açısından kendi konumu ile ilgili algısı şeklinde tanımlanmıştır. Yalnız hastalığın kaybolması değil aynı zamanda fiziksel, mental ve sosyal iyi olma hali, etkinlik, maliyet-yarar ve yeni terapötik stratejiler açısından SYK giderek önem kazanmaktadır (1). Yaşam kalitesi ölçeklerinin kullanımı çoğu ülkede olduğu gibi Türkiye'de de henüz araştırma düzeyinde sınırlı kalmış ve rutin kullanımı birkaç klinik dal dışında klinik ortama yeterince taşınamamıştır.
Nöro-yoğun bakımda nörolojik açıdan en ağır, tanı ve tedavi süreci en yoğun hasta grubu izlenmektedir. Yoğun bakımda izlenmesi gereken nörolojik hastalık grupları kronik dönemde olduğu gibi akut ve şiddetli evrelerinde de yaşam kalitesini etkilemektedir. Nöro-yoğun bakım süreci, sağlıkta yaşam kalitesini etkileyebilme potansiyeline sahip pek çok parametre içermektedir. Hastalıkların kendilerine ait yaşam kalitesi etkileri dışında, çok sayıda önemli parametre vardır. Bunları başlıca yoğun bakımda özellikle geriatrik populasyonda sık görülen premorbid multiorgan yetmezlikleri, beslenme yetersizliği, ajitasyon, ağrı, cilt bütünlüğünün bozulması, kas iskelet sistemi etkilenmeleri, kardiyovasküler ve otonom etkilenmeler, ilaç yan etkileri ve çoklu ilaç etkileşimleri olarak sıralamak mümkündür. Bu gibi parametrelerin 
etkisi ile gelişmiş ülkelerde yoğun bakım hastalarında mortalite oranı \%16,5-32,5 arasında değişmektedir. Taburcu olduktan sonraki en az 2 yıl boyunca fiziksel, psikolojik ve bilişsel işlev bozukluğu olanlarda SYK etkilenip daha yüksek mortalite ve morbidite oranı tespit edilmiştir (2). Sağlıkta yaşam kalitesi ölçümü tedavi planlamaya, değerlendirmeye ve klinik karar vermeye katkıda bulunabilecek olan ve güncelliği giderek artan bir konudur. Bu nedenle ülkemiz nöroyoğun bakım ünitelerinde takip edilen hastaların beslenmeye spesifik sağlıkta yaşam kalitelerinin takibi için bir standart oluşması morbiditesi çok yüksek olan bu populasyonda hayat kalitesini artırmaya katkıda bulunacaktır.

Bu derleme de nörolojik yoğun bakımda beslenme ile sağlıkta yaşam kalitesi arasındaki ilişki gözden geçirilecektir. SYK ölçümünde nöroyoğun bakıma spesifik kantitatif değerlerin tespiti için öncelikle beslenmenin biyolojisinin ve bozukluklarının ayrıntılı irdelenmesi gerekmektedir.

\section{Nörolojik Yoğun Bakımda Beslenme ve Metabolizma}

İnsan metabolizması yüksek ısılarda organik yakıtları yakarak oksidasyon denilen bir olay sonu enerji salınımı ortaya çıkarır. Oluşan enerji organik yakıtların gram başına kcal üretimi şeklinde ifade edilir ki bu yakıtlar karbonhidratlar $(3.7 \mathrm{kcl} / \mathrm{g})$, proteinler (4.0 kcal/g) ve lipitlerden oluşur $(9.1 \mathrm{kcal} / \mathrm{g}) \mathrm{dir}(3)$. Bazal enerji gereksinimi (BEG) Harris Benedict denklemi gibi sayıları 200'e kadar varan denklemlerle hesaplanabilmekle birlikte pratikte $\mathrm{kg}$ başına günlük 25-30 kcal olarak hesaplanmaktadır. Bu gereksinim istirahat, stres düzeyi ve diğer metabolik etkilere göre değişir ve beslenme planında bu faktörler dikkate alınarak gereksinim hesaplanır (4). Sağlıklı insanlarda doğal yollardan sağlanan bu enerjinin hastalıklar nedeniyle günlük intiyaçların altında kalması beslenme için desteğin temelini oluşturmaktadır. Özellikle nöroyoğun bakım hastalarının çoğunluğunu geriatrik, multisistem fonksiyonları sınırda olan hastalar oluşturur. Bu hastaların müdahale açısından dar bir terapötik pencereye sahip olması bu desteğin kolaylıkla hedefin altında ve üstünde olmasına neden olmaktadır. Bütünüyle enteral olarak istenen kaloriye ulaşmakta sıklıkla zorluk çekilmektedir. Bu durumun ise morbidite ve SYK üzerine olan olumsuz etkisi kaçınılmazdır.

Normalde günlük enerji alımının $\% 60-70$ i karhonhidratlar tarafından sağlanır ve glukoz beyin için ana enerji kaynağıdır. Aşırı alımı ise insülin salınımını stimule eder, insülin ise yağ dokusundan serbest yağ asidi mobilizasyonunu inhibe eder ve sonuçta endojen yağ kaynaklarını enerjideki rolünün bozulmasına neden olabilir (3). Bu nedenle yoğun glukoz kontrolünün önemi mortalite ve SYK açısından vurgulanmaktadır. Europan moderate control çalışmasına optimal kan şekeri seviyesi $140-180 \mathrm{mg} / \mathrm{dL}$ arası olarak belirtilmekle birlikte ASPEN110-150 mg/dL arasında tutulması gerekliliğini vurgulamaktadır (4). Lipitler ise organik yakıtların enerjisi en yüksek olan majör endojen yakıttır. Çoğunlukla beslenme rejimlerinde diyetin \%30 u ekzojen lipitlerce sağlanmaktadır (3). İlk 7 günde soya bazlı lipit içermeyen parenteral beslenme (PB) azalmış infeksiyon morbiditesi, azalmış hastane ve yoğun bakım kalım süresi ve kısalmış mekanik ventilasyon süresine sahiptir (5). Karnitin yetmezliğinin klinik komplikasyonları kardiyomiyopati, iskelet kası miyopatisi ve hipoglisemidir. Beslenmenin lipit ayağındaki eksiklikler yukarıdaki organ fonksiyonlarında bozukluklara neden olarak morbidite ve SYK özerine olumsuz etki göstermektedir.

Protein gereksinimi normal metabolizmada 0.8$1 \mathrm{~g} / \mathrm{kg} / \mathrm{gün}$ iken hiperkatabolizma durumunda 1.2$1.6 \mathrm{~g} / \mathrm{kg}$ olur. Protein katabolizmasında ölçütü olan nitrojen dengesi sabit protein alımı durumunda günlük nonprotein kalori alımı ile doğrudan ilişkilidir. Pozitif nitrojen dengesinde yani enerjiyi sağlamada protein kaçışını azaltmak için yeterli nonprotein kalori miktarını sağlamak gerekir bunun yerine artmış protein alımı bu dengeyi korumak için istenen bir yol değildir. Maalesef yoğun bakımlarda protein gereksiniminin tanımı zordur. Ancak nitrojen dengesindeki değişiklikler ile, basit $\mathrm{kg}$ hesapları ile (1.2 ile $2 \mathrm{~g} / \mathrm{kg} / \mathrm{gün})$, veya nonprotein kalori nitrojen oranı (70/1 ile 100/1) ile kısmen hesaplanabilmektedir. Protein markerleri albumin, prealbumin transferrin c-reaktif proteindir ve protein seviyesinin tanımlanmasında geçerli olmayan akut faz reaktanlarıdır (4).

Glutamin içeren amino asit solusyonlarının yoğun bakım hastalarında infeksiyon komplikasyonlarını ve mortaliteyi azalttığı ile ilgili bariz kanıtlar elde edilmiştir (3). Protein kaybı enfeksiyon, onkotik basınç düşmesine bağlı kalp, akciğer yetmezliği, asit gibi komplikasyonlar, sarkopeni gibi durumlara neden olabilir ve SYK yı etkileyecek kronik komplikasyonlara neden olabilir. Vitaminler günlük diyetin esansiyel bir parçası olarak düşünülür. Özellikle tiamin kardiyak disfonkiyonu, metabolik bozukluklar (Wernicke ensefaloptisi), laktik asidoz ve periferik nöropatiyi önlemede önemlidir. Yetmezliği yoğun bakım hastalarında sıktır günlük ihtiyaç ise $3 \mathrm{mg}$ dır. 
Endojen depoların 10 günde tükenmesi sonrasında klinik bulgular ortaya çıkar (3).Yağda eriyen E vitamini ile suda eriyen $C$ vitamini eksikliği multiorgan yetmezliğinde rol oynayabilir. Kritik hastalıkta olan artmış biyolojik oksidasyon oranları bu vitaminlerin günlük gereksinimlerini artırır. Artmış vitamin gereksimi hipermetabolik durumlarda olur. Özellikler riboflavin, pridoksin ve tiamin belirgin azalabilir (4).

\section{Malnütrisyon}

Total enerji alımının normalin alt veya üst seviyesinde olması demektir. Beslenme bozuklukları sonucu oluşacak hem nörolojik (serebrovasküler hastalıklar, ağır demyelinizan nöropatiler ve miyopatiler, hipoksik ve metabolik beyin sendromları, ağır ensefalitler, apse ve tümör gibi beyinde yer kaplayıcı lezyonlar) hem de multisistemik bozukluklar (kalp, böbrek akciğer yetmezlikleri gibi) mortalite, morbiditenin artmasına ve SYK nın bozulmasına neden olur. Malnutrisyon nörolojik hastalıklarda \%5565 oranındadır. Beslenmenin değerlendirilmesi;

1. Klinik değerlendirme; anamnez, fizik muayene (kas atrofisi, glossit, ödem, döküntü. Vücut ağırlığında değişme; son üç aydaki hafiften $(<\% 5)$ ağıra $(>\% 10)$ istemsiz kilo kayıpları. Kas fonksiyonları testleri (el dinamometresi, solunum kaslarının gücü)

2. Antropometrik ölçümler (Vücut kitle inteksi :kg / m2. <18: malnutrisyon, 18-20: malnutrisyon riski, 20-25 normal >30: obezite. Üst kol çevresi . $(k<18$, $\mathrm{E}<20 \mathrm{~cm})$. Triseps deri kıvrım kalınlığı : $(\mathrm{K}<13 \mathrm{~mm}$, $\mathrm{E}<10 \mathrm{~mm}$ )

3. Biyokimyasal parametreler (albumin, prealbumin, retinol bağlayıcı protein gbi)

4. İmmunolojik testler

5. Vücut kompozisyonu çalışmaları

6. Çok parametreli indeksler;

a. Nutrisyonel risk tarama (NRS),

b. Subjektif global değerlendirme (SGD).

c. Malnutrisyonel universal tarama testi (MUST).

d. Mini nutrisyonel değerlendirme (MNA) gibi (6).

$\mathrm{Bu}$ tür geleneksel beslenme değerlendirme araçları nöroyoğun bakımda bireysel olarak değerlendirilmelidir. Albumin prealbumin, retinol bağlayıcı globulin gibi biyokimyasal parametreler akut faz cevabının, ani vasküler permeabilitede artışın sonucu oluşabilir ve beslenme durumu hakkında direk bilgi vermemektedir (4).

Beslenmenin Planlanması ve Başlama Rejimleri Üç başlık altında toplanmaktadır. 1. Enteral beslenme, 2. Parenteral beslenme, 3. Kombinasyon

\section{Enteral Beslenme}

İlk etapta düşünülmesi gereken beslenme yolu enteral beslenmedir (EB) dir. Geleneksel enteral başlama rejimleri dilüe formulasyonu olan hipoosmolar mayilerle ve yavaş infüzyon şeklindedir. Bunda amaç hastanın tolerasyonunu sağlamak ve hazımsızlık ve ishal gibi dispeptik şikayetlerin oluşmasını engellemektir. Tedricen artırılarak birkaç güne kadar arzulanan beslenmeye ulaşılır. Hospitalizasyonun ilk haftasına amaçlanan kalorinin \%50-65'inden fazlasının sağlanabilmesi faydalıdır. Ancak intragastrik total başlangıçlı beslemelerde de kusma veya diyare gibi komplikasyonlar gözlenmeyen bazı çalışmalar total dozun hemen verilebileceğini söylemektedir 7-10 gün içerisinde istenen kalori düzeyine ulaşılamayan hastalarda PB yöntemi düşünülmelidir (4).

EB barsak kan akımını stimule ederek intrapetielial hücreler arasındaki sıkı bağlantıların idamesini sağlar ve böylece barsak fonksiyonel bütünlüğünü korur. İntestinal epitelyum patojenik mikroorganizmaların invazyonu için bir barıyerdir. Bu barıyer fonksiyonu traktus boyunca besinlerin kitle şeklinde ilerlemesi ile devam eder. Besinlerin azalması barsak mukozasında dejeneratif değişikliklere yol açar. Bu dejenerasyonu önlemede önemli rol oynayan proteinlerden bir tanesi intestinal epitelyum hücrelerinin primer metabolik yakıtı olan glutamindir. Barsak istirahati sırasında enterik patojenlerin translokasyon sürecine girdiği yoğun bakım hastalarında belgelenmiştir (3). EB de standart besleme dışında immunmodulatör enteral formulasyonlar (arginin glutamin nükleik asit omega 3 yağ asidleri ve antioksidanları içeren) uygun hasta populasyonları için kullanılabilir (4). Metanalizler göstermiştir ki immun modulatör formulasyonlar mekanik ventilasyon süresinde ve hastanede kalış süresinde anlamlı azalma ile ilişkilidir (4). Akut respiratuvar distres sendromu ve şiddetli akut akciğer hasarı olan hastalarda antiiflamatuar lipit profili ve antioksidanlarla karakterli enteral formulasyonlar yer almalıdır (omega 3 yağ asitleri, gama linolenik asid ve antioksidanlar hastanede kalış süresini azaltmakta ancak dozları tartışmalı kalmaktadır). Optimal terapötik etkiyi immun modülatör formülasyonlardan elde edebilmek için enerji gereksiniminin en azından \%50-65 oranında bu yolla sağlanması gerekir (4).

\section{Parenteral Beslenme}

Enteral beslenme ile tam bir beslenme desteği mümkün olmadığı zaman PB destek olarak kullanılabilir (7). PB Protein kalori malnutrisyonu kanıtı olan hastalarda EB uygun değilse hastaneye yatar yatmaz PB başlanır. Son kilo kayıpları \%1015 ise veya normal kilosunun \%90'ından azında ise PB kullanımı standart kristalloid tedavisine 
daha üstündür (4). PB alan tüm hastalarda kısmen yetersiz beslenmeye izin verilebilir hesaplanan enerjinin \%80 inin hedeflenmesi uygundur (4). PB ile stabilize olan hasalara periyodik olarak EB başlama çabaları gösterilmelidir. Kademeli EB artırılırken PB azaltılabilir. EB ile enerjinin \%60'ı sağlanmadıkça PB sonlandırılmamalıdır (4).

\section{Yaşam Kalitesi Üzerine Kullanılan Bazı Testler}

Tüm bu besleme yöntemlerinde oluşacak yetersizlikler morbidite ve SYK'nin olumsuz etkileyecektir. Birçok SYK ölçeği bulunmakla birlikte nöroyoğun bakımda beslenme ile ilgili spesifik bir skala bulunmamaktadır. Yaşam kalitesi ölçümünde metod olarak "self rating" in kullanılması tercih edilir çünkü değerlendirmelerin önemli bir bölümü bireyin subjektif algısına bağımlıdır. Özellikle emosyonel iyi hissetmeyi başka bir ölçüm sağlayamaz. Ancak bilişsel olarak ehil olmayan hastalarda yalnızca "Proxy rating" skalalar kullanılmak zorunluluğu vardır, "self rating" için bilinçlilik gerekmektedir (8).

\section{Yoğun bakımda yaşam kalitesini değerlendirmede kullanılan bazı testler;}

- SF-36; (self ve proxy rating); Sekiz konsept içerir. Sağlık problemleri nedeniyle fiziksel aktivitelerde kısıtlılık, fiziksel veya emosyonel problemler nedeniyle sosyal aktivitelerde sınırlamalar, fizikse sağlık problemleri nedeniyle genel rol aktivitelerinde sınırlıık, vücut ağrısı, genel mental sağlık durumu (psikolojik stres ve iyi olma hali), emosyonel problemler nedeniyle genel rol aktivitelerinde azalma, vitalite (enerji ve düşkünlük), genel sağlık algısı. Enerji ve yürütücü fonksiyonları da sorgulanmaktadır $(1,9,11)$.

- EQ-5D Genel Yaşam Ölçeği (European Quality of life intstrument), (self ve proxy rating). Hareket, özbakım, iş, ders çalışma, ev işleri gibi olağan faaliyetler, ağrı ve rahatsızılı, ve anksiyete depresyon aktiviteleri. Ancak yeme ve komplikasyonları üzerine belirgin bir sorgulama bulunmamaktadır $(9,12,13)$.

- Nottingham Sağlık Profili (NHP) (self rating); fiziksel kabiliyet, ağrı, emosyonel reaksiyonlar, enerji seviyesi, uyku sosyal izolasyon problemleri ile ilgili sorular sorulmaktadır. Enerji, egzersiz tolerans fonksiyon üzerine özellikli soruları bulunmaktadır $(9,14)$.

- Sickness impact profile (SIP) (self rating); uyku, istirahat, yeme, çalışma ambulasyon, mobilite, vücut bakımı sosyal etkileşim, bilinçlilik, davranış, emosyon ile ilgili sorular sorulmaktadır. Stroke spesifik verisyonu SA SIP30 dur. Enerji, egzersiz tolerans fonksiyonları, yeme, içme ve defekasyon fonksiyonları ile üriner fonksiyonlar sorgulanmaktadır $(9,15)$.

- Stroke impact scale; SIS (self ve proxy rating); kuvvetlilik, hafıza, düşünme emosyon, mobilite, el fonksiyonları, katılım ile ilgili sorular sorulmaktadır. Yeme, defekasyon ve üriner problemler ile ilgili sorular içermektedir $(9,16,17)$.

- Stroke specific quality of life scale (SSQol); (proxy rating); özbakım, vizyon, dil, mobilite, çalışma üst ekstremite fonksiyonları, düşünme, mood, sosyal roller enerji üzerine sorular sorulmaktadır. Enerji, egzersiz tolerans fonksiyonları, yeme fonksiyonları sorgulanmaktadır $(9,18)$.

- Burden of stroke scale (BOSS); mobilite, özbakım, yutma enerji, uyku, mood, kognisyon, sosyal ilişki ile ilgili sorular sorulmaktadır. Enerji ve yürütücü fonksiyonlar, yeme fonksiyonları sorgulanmaktadır $(9,19)$.

- QLQ-C30 çekirdek soruları 8 fonksiyonel alanı içerir ikisi fonksiyonu fiziksel yönünü (fiziksel ve rol fonksiyon), üçü psikososyal fonksiyonu (emosyonel kognitif, sosyal fonksiyon), ayrıca fiziksel semptom aralığını değerlendiren sorular sorulur (düşkünlük, bulantı kusma ağrı dispne uyku bozukluğu iştah, konstipasyon diyare gibi) ve ayrıca finansal zorlukları sorgulanmaktadır (20).

Nöroyoğun bakım hastaları beslenme açısından kritik önemde bir hastalık grubudur. Beslenmenin SYK üzerine etkisi iki ana başlıkta toplanabilir. Birincisi beslenme bozukluklarının oluşturduğu sekonder yetmezliklerin morbiditeyi ve uzantısı olarak SYK üzerine etkisi, ikincisi ise hastane ve sonrası dönemde beslenme için kullanılan yöntemlerin SYK üzerine olan etkisidir. Beslenme yöntemleri üzerine yapılan SYK çalışmalar;

Evde parenteral beslenme ile karşılaştırılınca evde enteral tüp beslenme daha basit daha ucuz bir teknik olup daha az komplikasyonla yaşam kalitesini yükseltir. EB ile tam sağlanamayan protein enerji intiyacı için kombine edilen PB yoğun bakım hastaları için uygun bir beslenme yöntemidir (20). Enteral beslemede ise kısa dönemde nazogastrik tüp beslenme kullanılır, gastrostomi ve jejunostomi ise uzamış veya persistent durumlarda tercih edilir. Nazogastrik tüpün perkütan endoskopik gastrostomiden daha az tolere edildiği rapor edilmiştir. Evde enteral beslenme ile yapılan iki çalışma SYK de değişiklik olmadığı yönündedir. Majör şikayetler diyare, vücut imaj bozukluğu (tüpün uzun sürmesi) diurnal ve nokturnal susama, yiyememe idi. Tüm bu durumların depresyonu indükleyebileceği belirtildi (20).

Enteral beslenme ile ilgili ender yapılan 
çalışmalardan Cowen et al. (21) çalışmasında (Self rating için QLQC30 uygulandı) perkütan endoskopik gastrostomili hastalar iki kat uzun yaşadığı belirtildi. Çalışması yutma güçlüklü hastalara sınırlı olduğu için diğer populasyonlara göre ömrün 2 kat uzaması genellenemediği ve hasta yaşam kalitesi hakkında bir fikir vermediğini belirtmektedir. Tüm bu çalışmalarla birlikte prospektif verilerin olmaması, farklı testlerin kullanılması, hiç birinin perkutan endoskopik gastrostomi için spesifik olmaması gibi dezavantajlarla birlikte SYK üzerine etkisi farklı testlerin kullanımından bağımsızdır denilmektedir. Gelecek araştırmalarda enteral tüp ile beslenen hastaların subjektif ve objektif tecrübeleri SYK için bir ölçüm sağlayabilir (8). Yaşam kalitesi ölçümleri hastalığın klinik sonuçları ölçümlerinin yerini alamaz ama tedavi planlamaya değerlendirmeye ve klinik karar vermeye katkıda bulunabilir (22).

Nöroyoğun bakım hastalarında beslenmenin SYK üzerine etkisi için bu enstrumental yaklaşımların etkileri ile birlikte uzun dönem morbiditenin yaşam kaliteleri üzerine olan etkilerini bilerek onlarla mücadele etmenin de (malnutrisyona bağlı polinöropati, enfeksiyon yatkınlığı, sarkopeni, kalp ve böbrek yetmezliği gibi sistemik morbidite kaynakları) SYK üzerine etkinliği göz önünde bulundurulmalıdır.

Çıkar Çatışması: Çalışmada herhangi bir çıkar çatışması yoktur.

Finansal Çıkar Çatışması: Çalışmada herhangi bir finansal çıkar çatışması yoktur.

Yazışma Adresi: Osman Serhat Tokgöz, Necmettin Erbakan Üniversitesi, Meram Tıp Fakültesi, Nöroloji Anabilim Dalı, Konya, Türkiye, 42081.

E-mail:serhatnoroloji@yahoo.com.tr

Tel: 03322237784

\section{KAYNAKLAR}

1. Testa MA, Simonson DC. Assesment of quality-of-life outcomes. N Engl J Med 1996;334:835-40.

2. Cieza A, Stucki G. Content comparison of health-related quality of life (HRQOL) instruments based on the international classification of functioning, disability and health (ICF). Qual Life Res 2005;14:1225-37.

3. Marino P. Nutrition and metabolism. In: Marino P, ed. The ICU book. 3rd ed. Philadelphia: 2007:866-936.

4. McClave SA, Martindale RG, Venek VW, et al. Guidelines for the provision and assessment of nutrition support therapy in the adult critically III patient: Society of Critical Care Medicine (SCCM) and American Society for Parenteral and Enteral Nutrition (A.S.P.E.N.). JPEN J Parenter Enteral Nutr 2009;33: 277-316.

5. McCowen KC, Frie C, Sternberg J, et al. Hypocaloric total parenteral nutrition: Effectiveness in prevention of hyperglycemia and infectious complications a randomized clinical trial. Crit Care Med 2000;28:3606-11.

6. Moral AR, Uyar M. Yoğun bakımda nütrisyon desteği. Yoğun bakım derneği dergisi 2006;4:6-12.

7. Dudrick SJ. Early developments and clinical applications of total parenteral nutrition. JPEN J Parenter Enteral Nutr 2003;27:291-9.

8. Loeser C, Von Herz U, Küchler T, et al. Quality of life and nutritional state in patients on home enteral tube feeding. Nutrition 2003;19: 605-11.

9. Geyh S, Cieza A, Kollerits B, et al. Content comparison of health-related quality of life measures used in stroke based on the international classification of functioning, disability and health (ICF): A systematic review. Qual Life Res 2007;16: 833-51.

10. Hagen S, Bugge C, Alexander H. Psychometric properties of the SF-36 in the early post-stroke phase. J Adv Nurs 2003;44:461-8.

11. Hobart JC, Williams LS, Moran K, et al. Quality of life measurement after stroke: Uses and abuses of the SF-36. Stroke 2002;33:1348-56.

12. Dorman P, Slattery J, Farrel B, et al. Qualitative comparison of the reliability of health status assessments with the EuroQol and SF-36 questionnaires after stroke. United Kingdom Collaborators in the International Stroke Trial. Stroke 1998;29:63-8.

13. Pickard AS, Johnson Ja, Feeny $\mathrm{DH}$, et al. Agreement between patient and proxy assessments of health-related quality of life after stroke using the EQ-5D and Health Utilities Index. Stroke 2004;35:607-12.

14. Gosman-Hedstrom G, Claesson L, Blomstrand C. Consequences of severity at stroke onset for health-related quality of life (HRQL) and informal care: A 1-year follow-up in elderly stroke survivors. Arch Gerontol Geriatr 2008;47:7991.

15. van Straten A, de Haan RJ, Limburg $M$, et al. A strokeadapted 30-item version of the sickness impact profile to assess quality of life (SA-SIP30). Stroke 1997;28:2155-61.

16. Duncan PW, Bode RK, Min Lai S, et al. Rasch analysis of a new stroke-specific outcome scale: The stroke impact scale. Arch Phys Med Rehabil 2003;84(7):p. 950-63.

17. Duncan PW, Wallace D, Studenski S, et al. Conceptualization of a new stroke-specific outcome measure: The stroke impact scale. Top Stroke Rehabil 2001;8:19-33.

18. Williams LS, Weinberger M, Harris LE, et al. Development of a stroke-specific quality of life scale. Stroke 1999;30:1362-9.

19. Doyle PJ, McNeil MR, Mikolic JM, et al. The Burden of Stroke Scale (BOSS) provides valid and reliable score estimates of functioning and well-being in stroke survivors with and without communication disorders. J Clin Epidemiol 2004;57:9971007.

20. Roberge C, Tran M, Massoud C, et al. Quality of life and home enteral tube feeding: A French prospective study in patients with head and neck or oesophageal cancer. $\mathrm{Br} J$ Cancer 2000;82:263-9.

21. Mitchell SA, Leidy NK, Mooney $\mathrm{KH}$, et al. Determinants of functional performance in long-term survivors of allogeneic hematopoietic stem cell transplantation with chronic graftversus-host disease (cGVHD). Bone Marrow Transplant 2010;45:762-9.

22. Higginson IJ, Carr AJ. Measuring quality of life: Using quality of life measures in the clinical setting. BMJ 2001;322:1297300. 